Makale türü / Article type: Araştırma / Research

\title{
Toprak ve İnsan: Birkaç Edebi Metinde ve Avesta'da Toprağın Yansıması
}

$* * *$

\section{Land and Human: Land Reflection in a Few Literatures and Avesta}

\author{
Araş. Gör. Dr. Yunus Arifoğlu \\ Eskişehir Osmangazi Üniversitesi, Fen-Edebiyat Fakültesi, \\ Tarih Bölümü, ynsarfglu@gmail.com
}

(ORCID: 0000-0001-7931-8617)

\begin{abstract}
Özet
Toprak, insanın üzerinde yaşadığı ve ona bağlı olduğu en eski ve temel unsur olarak kabul edilir. $\mathrm{Bu}$ nedenledir ki eski iktisadi sistemler toprağa bağlı bir biçimde şekillenmişlerdir. İnsanın yerleşik hayata geçmesiyle, toprak insan hayatında belirleyici olmuştur. Toprağın sahip olduğu bu önem nispetinde bir sisteme bağlı olması zorunluydu. Bu ihtiyaca binaen Eski Çağdan itibaren işlenen toprak, bir sisteme bağlı gelişerek belli bir olgunluğa erişmişti. Ortaçağ'da gelişen toprak sistemleri, Eski Çağın birikimi olan sistemlere dayalı olmuş ve bu sistemler revize edilerek günün koşullarında yeniden yorumlanmışlardır. Bu çalışmada insanın toprakla ilişkisi öncelikle birkaç edebi metin üzerinden tartışılacak, ardından dini metinlerden olan Avesta'nın toprak üzerindeki etkilerine bakılacaktır.
\end{abstract}

Anahtar Kelimeler: İnsan, Toprak, Avesta

Jel Sınıflandırması: Q15

\begin{abstract}
Absract
Land is regarded as the oldest and most basic element in which man lives and is attached to it. For this reason, old economic systems were designed depending on the land. With the transition to settled life, land became the determinant of human life. The land must have been connected to a system. Because of this need, the land was connected to a system. The land systems developed in the Middle Ages were reinterpreted under the conditions of the day, based on the systems that make up the accumulation of ancient times. In this study, the relationship between man and land will be seen through various literary texts. Then the effects of Avesta on land will be examined.
\end{abstract}


Keywords: Human, Soil, Avesta

Jel Classification: Q15

\section{GIRIŞ}

Eski ve orta zamanda medeniyet toprak ve ona bağlı değişkenler üzerinden şekilleniyordu. Toprağın verimli ya da çorak olması medeniyetin gelişiminde belirleyici olmaktaydı. İnsanın yaşam biçimi de toprağın cömertliği ekseninde biçimlenirdi. $\mathrm{Bu}$ dönemlerde toprağın işleyişinin değişimi medeniyetin yönünün değişiminde önemli bir etkendi. İnsan, uzun uzadıya bir zaman diliminde yeryüzünde azlığının verdiği rahatlıkla toprak toprak gezerek, her çiçekten nektar alan arılar gibiydi. Toprak ürün vermeyecek duruma ulaştığında ıslah yeteneği henüz bilinmediğinden başka topraklara göç başlardı. Nüfusun artmasıyla birlikte ve gidilen bölge artık uzak ve elverişsiz olunca, toprağın işlenmesi zorunlu bir hale geldi. Böylece uzun tecrübeler sonucunda Neolotik dönem ile tarım insan hayatına girerek, hayatın mecrasını yerleşik bir şekle büründürdü. (Ritter, 1962: 1, Bilge, 1946: 13 ve Öz, 2014: 7)

Ortaçağ' da iktisat, esas itibariyle toprağa dayalıydı. Bu dönemde çiftçi kadar, zanaatkâr, esnaf ve tüccar varlığını toprağa borçluydu. İnsanların zorunlu ihtiyac1 olan pamuk ve keten gibi giyimin ham maddesi topraktan bitmekteyken, çiftçi için gerekli olan aletlerin üretimi ve topraktan biten bu ham maddelerin işlenilmesi zanaatkâra ihtiyaç bırakmaktaydı. Ürün fazlası ve sanayi ürünlerinin işlenmesi küçük atölyeleri oluşturmaktaydı. Çiftçinin merkeze getirdiği ürün fazlasını, işinden geri kalmamak için şehirde bırakmasıyla esnaf teşkilatı oluşurken, ürün fazlasının bir bölgeden diğer bölgelere taşınması ise ticareti ve de dolayısıyla tüccarı meydana getirmiştir. Yine buna bağlı olarak ağaç dikimi, hayvancılık ve gibi işler toprağa dayalı, toprağın sağladığı imkânlar dâhilinde mümkün olmaktaydı.

Ortaçağ'da mülk anlayışı ilahî esas çerçevesinde idi. Hükümdar, mülkün vekili, ona vekâlet edendi. Bu anlayışla toprağ 1 işleyen vatandaş toprağın sahibi değil, bekçisi konumundaydı. Devletin vazifesi ise toprağın işlenmesinde düzeni tesis etmek idi. Düzenin tesisi için gerekli olan maliyet, topraktan elde edilen ürünlerin belli bir oranda verilmesiyle sağlanmaktaydı. 
Ortaçağ' da toprağın sahip olduğu öneminden dolayı işlendiği sistem de önem kazanmaktaydı. Bu sistemler sadece iktisadı değil, sosyal yapı ve aileyi de şekillendirmişti. Toprağa dayalı idari sistemler feodal yapılar, sosyal yapının önemli bir parçasıydı. Bu dönemler boyunca toprak, sahip olduğu önemi itibariyle Sanayi Devrimine kadar merkezde yer almıştır.

\section{Bazı Edebi Metinlerde İnsanın Toprakla İlişkisi}

Ortaçağ'da insanın hikâyesi topraktan toprağa dönüş olarak görülmekteydi. Bu dönem insanının toprağa ehemmiyet vermesi ondan gelip ona gitmedeki arazamanda yüklediği değerle şekillenmiştir. Âşık Veysel'in iki kapılı han'a benzettiği bu durum, insanın hikâyesinin özetidir. Yakın zamana kadar insanın topraksız kalması köksüz kalmasıyla eş tutulmuş, topraksızlık bahtsızlık olarak bilinmiştir. Hemen her şeyi toprak üzerinden şekillenen insanın, toprağın eski ve orta çağlarda hayatında oynadığı rolün önemli bir yeri vardır. İnsanın toprakla ilişkisi et ile tırnak şeklini almıştı. Sanayi devrimine kadar bu ilişki yoğun bir şekilde sürerken, bu süreçle birlikte ağırlık ekseni başka yönlere kaymış olsa da, toprak önemini teknoloji devrimine kadar korumuştur. Hala eski insanların toprakla ilişkisi yeni nesillerden farklı bir biçimde gelişmekte, onlar için toprak çocukları kadar değerli olmaktadır (Zerdüşt Spitama, 1998; Bilge, 1946; Berat, 2004).

Toprak mitolojide temel unsurdur. Yine felsefenin dört unsurundan birisi topraktır. Toprak, bu önemi nispetinde şiirlerde, edebi eserlerde kendisine yer bulmuştur.

Toprak Türk mitolojisine de yansımış, dünyanın oluşumu bunun üzerinden hikâye edilmiştir. Yunan mitolojisinde de evrenin ve dünyanın oluşumu Gaia üzerinden şekillenmiştir. (Töret, 2019: 272).

Arif Nihat Asya'nın,

"Ben yürürken çıtırpıtır konuşan/ Yüreğim, san'atım, dilim toprak" (Asya, 1976: 19, 21-22). İnsanın toprağa verdiği değeri onunla kendisini eş tutacak düzeydedir.

Azra İnal'1n, 
"Bana toprak verin toprak/üzerinde yatılacak/kapısı penceresi toprak/elinle okşamak istediğin koklamak istediğin toprak/etin kanin kemiğin toprak" (İnal, 1950: 1) dizeleri insanın toprakla ilişkisinin bir aşka dönüşmesini anlatır.

Aşık Veysel,

"Dost dost diye nicesine sarıldim

Benim sadık yârim kara topraktır

Bir çekirdek verdim dört bostan verdi

Benim sadık yârim kara topraktır" (Berat, 2004: 246).

Aşık Veysel bu dizileriyle insanın toprakla bağımlılı̆̆ını gerçekçi bir biçimde tasvir etmektedir.

İran'ın destansı şah eseri kabul edilen Firdevsi'nin Şehnamesinde, toprağa dair insanın hayata, çalışmaya bakışını sunar,

"Toprakta çalı̧sanlar, ekenler, biçenler ve yiyip içmek hususunda kimseye minnet etmeyenler onlardir. Yeryüzü onların sayesinde mamur" (Firdevsi, 1956: 40).

Ahmet Hamdi Tanpınar'ın Beş Şehir eserinde Erzurum'u anlattığı bölümde geçen,

"Bu iki Cinisli bana insanoğlunun sadece toprakla temas ederek yaptı̆̆ bir arınmanın muzaffer, ilahi mahsulleri gibi geldi" (Tanpınar, 2016, 60). Cümlesi insanın toprakla ilişkisinin vücut bulmuş halidir.

Toprağın yegâne iş, aş alanı olması, kutsal kitapların insanın varlığını devam etme, neslini devam ettirme, canını koruma ve besleme üzerine eğilmeleri, insana toprağa değer vermeleri noktasında öğüt verme durumunu doğurmuştur. Toprak, hem tecrübe hem de kutsal kitapların öğütleriyle bir kültür halinde insanların düşünce, anlayış, hayata bakış ve alışkanlıklarının esasının belirleyicisi olmuştur. Bununla birlikte toprak, insanın şahsiyetini, karakterini, toplumsal davranış şeklini belirlemede bir kıstas haline gelmiştir. Toprakta çalışmak insanı minnet etmekten kurtarır anlayışı, bugün dahi çalış ki minnet etme anlayışıyla bağdaşmaktadır/eştir. Yine hür insan vurgusu ve 
bunun karşıtlığında oluşturulan diyalektik önemlidir. Hz. Peygamber şöyle buyurmakta, Kim ziraat yapar veya ağaç diker de onlardan insan, hayvan ve kuş yerse bu onun için sadakadır (Yahya b. Adem, 1964: 106).

\subsection{Avesta'da Toprak Anlayışı}

Dinler insanın hayatta kalma gerçeği üzerinden insanı çalışmaya yönlendirmiştir. Eski zamanda çalışmak denilince akla toprak ve toprağa yardımcı işler gelirdi. Zerdüştlük, toprağa önem vererek, insanı toprakta çalışması için yönlendirmiştir. Bu nedenle eski İran'da ziraat dini bir vecibe anlayışına sahipti. Avesta'da ziraat oldukça övülen bir uğraş, dini bağlamda bunun sevap getiren bir eylem olduğu yargısı kutsal kitap tarafından belirtilmiştir. Zerdüştlük'ün toprağa verdiği bu önemi nispetinde de olsa gerek İran'da tarımın ilerlediği belirtilmektedir (Altungök, 2015: 71). Avesta'ya geçen Zerdüştlük'e ait mitler, bir toplumun, dinin, hayata ve toprağa dair izi görülebilmektedir. Zerdüştî bayramlarında önemli bir hadise olan geleneksel ejderha öldürme merasimi bunun iyi bir örneğidir.

“İnanışa göre ejderha yağmuru tutarak yağmasını engelliyordu. Bu da ülkede kuraklığa sebebiyet vermekteydi. Bir kahraman çıkarak ejderhayı öldürür. Kahraman kutsiyet kazanırken, yağmurun önündeki engel kalkmış olurdu. Böylece toprağa bereket gelirdi. Aynı zamanda kutsal kahraman ejderhanın mağaraya kapattığı kizlarla da kutsal düğ̈̈nünü yapardı (Zerdüşt Spitima, 1998: 49).

Avestada geçen, hayvanları koruyacak, merada otlatacak, bilgeliğin yolu, mutluluğun gelişimi, hasadın güzelliğinden geçer metinleri Zerdüştlük'ün toprağa bakışını netleştirebilir. Zira bu bakış sonrasında İran toplum hayatında toprak, önemli bir değere sahip olmuştur (Zerdüşt Spitima, 1998: 49 ve Schwartz, 1985: 641-649) Uzun uzadiya geçen bir metinde Varlıkların Yaratıcısına sorulan yeryüzünün mutluluğunu derecelendirmesinin istenmesi, öncelikli olarak geniş meraların bakımı, hayvanların korunması, beslenmesi olarak cevap bulur. Yeryüzünün üçüncü mutluluğu ekinlerin, çayırların, yenebilecek meyve ağaçlarının ve toprağın olduğu yer kabul edilmiştir. Bilge insan için, din adamıyla, karısı, oğluyla birlikte hayvanları ve onlar için inşa ettiği ev gelir (Zerdüşt Spitima, 1998: 
69). Tanrıya yeryüzünü neşelendireni soran Zerdüşt, buna mukabil, en fazla tahıl, ot ve meyve tohumu serpen, kuru toprağı sulayan ve bataklık toprağı kurutan kişi cevabı alır.

En makbul kişi, ekin eken, çayır yetiştiren, yenebilecek meyve ağacı diken ve kurumuş toprağa su bulandır. Toprağın uzun süre nadasa bırakılmaması noktasında da hassasiyet gösterilmiş, uzun süre ekilmeyen toprak sevinmez, hep kendisini sürebilen birini bekler durur, cümlesiyle toprağa insan özellikleri olan duygusallıkla yaklaşılmıştır (Zerdüşt Spitima, 1998: 46, 105). Yine uzun süre ekilmeyen toprak mutsuzlukla ifadelendirilmiş, çocuksuz kalmış ve iyi bir koca isteyen güzel evlenmemiş bir kadın gibi iyi bir çifti ister benzetmesiyle toprağın işleyişi neslin devamı olarak görülmüştür. İnsanın çalışma felsefesi toprağın diliyle anlatılmış, toprağın dilinden kendisini işleyen ile işlemeyenin ayrımı yapılmıştır. Toprak kendisini işleyene cömert olurken, işlemeyene ise "El kapısında duracaksın" şeklinde beddua etmiştir. Yine toprak, "Tahıl eken doğruluk eker” cümlesinde olduğu gibi hayat felsefesinin belirleyicisi olarak insana yön vermeye çalışmıştır. "Bu toprağa, kadınların olduğu bu toprağa senin olan bizleri ve kadınları taşıyan bu toprağa hürmet ediyoruz" ifadesi toprağın kadınla ilişkilendirilmesi ise ayrıca öneme sahiptir (Zerdüşt Spitima, 1998: 73).

Bizatihi Ahura Mazda'nın Zerdüşt'e söylediği şu ifadeler, "Bekler kendisini kullanabilenden iyiliği, tıpkı büyümüş genç ve güzel bir hanımın uzun zamandan beri çocuk özlemiyle erkeğinden gelecek iyiliği beklemesi gibi " ifadeler insanın toprakla bütünleşmesinin yansımasıdır.

Zerdüşt'ün sorduğu, dinlerdeki gerçek öz nedir sorusuna Tanr1; Çalışkan bir şekilde tohum eken, irfan ekmiş olur. O artık her şeyi Bilen'e tapanların dinini geliştirendir. Zerdüşt ile Tanrı arasında gerçekleşen bu diyaloglar Zerdüştlük'ün toprağa verdiği önemin bir yaşam biçimi olarak yerleştirilmek istendiğini göstergesidir. Toprağı ihya etmek, tohum atıp, sulamak, ağaç dikmek Zerdüşt felsefesinin bir parçasıdır (Zerdüşt Spitima, 1998: 73 ve Günaltay, 1948: 286). Bereket dolu bir erkek, kadın ve erkek çocuk hayvanlarıyla birlikte ocak kurarlarsa; o ev bereket dolar, orada yaşamın en güzeli oluşur. Zerdüş̧ü dininde Videvdat Tarım hayvanlarının 
meleği olarak bilinmesi de bu önemin bir parçasıdır (Zerdüşt Spitima, 1998: $36,44)$.

\section{SONUÇ}

Toprak, insanın üzerinden yaşadığı ve ona bağlı olduğu temel unsurdur. Mitolojide dünyanın yaratılışının bir unsuru olarak toprak görülmüştür. Ortaçağ'daki iktisadi sistemler toprağa bağlı bir şekilde gelişmişlerdir.

İnsanın hikâyesi, topraktan geldik toprağa gideriz felsefesiyle şekillenmiştir. Öyle ki bu felsefe insanın toprakla ilişkisinde et ile tırnak şeklini almasına neden olmuştur. İnsanın toprakla ilişkisinin en veciz hali Tanpınar'ın dizelerinde geçen, bu iki Cinisli bana insanoğlunun sadece toprakla temas ederek yaptığ bir arınmanın muzaffer, ilahi mahsulleri gibi geldi. İfadesiyle kendisine yer bulmuştur.

Ortaçağ'da toprak iş ve aş alanı olmuştur. Dinin insan neslini devam ettirme gayretinden dolayı da kutsal kitaplar insanı toprağı ekmeye ve işlemeye itmişlerdir. İnsanın varlığını devam etme, neslini devam ettirme, canını koruma ve beslenmesi topraktan bitenlerden mümkün olmuştur.

Toprak hem tecrübe hem de kutsal kitapların ögütleriyle bir kültür halinde insanların düşünce, anlayış, hayata bakış ve alışkanlıklarını belirlemiştir. Bununla birlikte toprak, insanın şahsiyetini, karakterini, toplumsal davranış şeklini belirlemede bir kıstas haline gelmiştir. Toprakta çalışmak insanı minnet etmekten kurtarır anlayışı yerleşmiştir.

Bugün dahi birçok öğütte çalış ki minnet etme anlayışı, bu kültürün devamını ve sürekliğini göstermesi açısından değerlidir. Bu kültür yerleşik hale gelmiş, yıllar y1lı insanın mizacını oluşturarak hürriyetini korumasında bir aracı rolü üstlenmiştir. Hâsılı hür kalabilmek çalışmakla eş değer hale gelmiştir.

\section{KAYNAKLAR}

Altüngök, A. (2015). Eski İran'da Din ve Toplum. İstanbul: Hikmetevi Yayınları.

Aslı B. T. (2019). Azerbaycan Türklerinin atasözlerine yansıyan toprak olgusu, Folklor Dergisi, 25(98), 267-277. doi: 10.22559/folklor.878

Asya, A. N. (1976). Ses ve Toprak. İstanbul: Ötüken Yayınları. 
Berat, A. (2004). Aşık Veysel. Ankara: Akçă̆ Yayınları.

Bilge, A. (1946). Tarih Boyunca Toprak. Konya: Ülkü Basımevi.

Firdevsi. (1956). Şehname-I. İstanbul: Maarif Basımevi.

İnal, A. (1050). Toprak. İstanbul: MCMLI.

Öz, E. (2014). Kültepe Metinleri Işı̆̆ında Eski Anadolu'da Tarım ve Hayvancılık. Ankara: TTK Yayınları.

Ritter, K. (1962). Ziraat Tarihi, (Çev. K. Köylü). AnkarA: Ankara Üniversitesi Ziraat Fakültesi.

Schwartz, M. (1985). The Old Eastern İranian World View To The Avesta, The Cambridge History Iran. New York: Cambridge Press,

Şemseddin,G. (1948). Iran Tarihi, Eski Çă̆lardan İskender'in Seferine Kadar. Ankara: TTK Yayınları.

Tanpınar, A. H. (2016). Beş Şehir, (35. Baskı). İstanbul: Dergah Yayınları.

Yahya b. Adem, (1964). Kitabu'l Haraç, thk. Ahmed Muhammed Şakir, Matbaatu'sSelefiyye, Kahire

Zerdüşt, Spitama, (1998). Avesta (Çev. E. Ayata). İstanbul: Kora Yayınları.

Zerdüşt, S, (2012). Avesta (Çev. F. Adsay \& İ. Bingöl). İstanbul: Avesta Yayınları. 